\title{
97. Definition of Coenomyiidae (Diptera). II
}

\author{
Genera of the Family
}

\author{
By Akira NAGATomi \\ Entomological Laboratory, Faculty of Agriculture, Kagoshima University
}

(Comm. by Sajiro Makino, M. J. A., June 3, 1975)

The diagnoses of Coenomyiidae were given by Nagatomi (1975a). The genera of Coenomyiidae are presented in this paper.

Key to genera of Coenomyiidae.

1. Antennal segment 3 annulated, porrect, and subulate; 4th posterior cell widely open and anal cell narrowly open or closed at wing margin; in 우 front broader toward an-

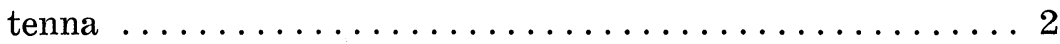

- Antennal segment 3 conical and with a long arista; 4th posterior cell (when vein $\mathrm{M}_{3}$ is present) and anal cell closed before wing margin (sometimes the latter closed at wing margin); in 우 front parallel sided; body slender, scutellum unarmed, and hind femur distinctly longer than mesonotum and scutellum combined .......... Dialysis

2(1). In antenna, segment 1 about as long as wide and segments $1+2$ less than $1 / 2$ as long as flagellum; head nearly as wide as or somewhat narrower than thorax (as well as in Dialysis) ; body slender or nearly so but sometimes (e. g. in Arthropeas magna Johnson) fairly robust .......3 3

- In antenna, segment 1 distinctly longer than wide and segments $1+2$ over $1 / 2$ as long as flagellum; head distinctly narrower than thorax; body robust ........4

3 (2). Scutellum with a pair of spine-like processes; hind femur distinctly longer than mesonotum and scutellum combined; body slender ................ Odontosabula

- Scutellum unarmed; hind femur not longer than mesonotum and scutellum combined (as well as in Coenomyia and Anacanthaspis); body somewhat slender to fairly

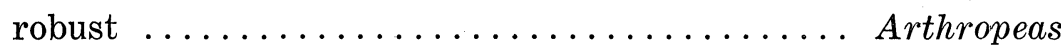

4(2). Scutellum unarmed, much wider than long, and its hind margin distinctly concave at middle and consisting of two more or less rounded portions; vein $\mathrm{M}_{4}$ arising from discal cell at or near m-cu crossvein (as well as in Dialysis, Odontosabula, and Arthropeas) or sometimes arising 
from m-cu crossvein; eye bare or practically so (as well as in Dialysis, Odontosabula, and Arthropeas) ; abdomen widest at segment 3 or $4 \ldots \ldots \ldots \ldots$ Anacanthaspis

- Scutellum trapezoidal or semicircular and with a pair of spine-like processes (which become small and inconspicuous in C. bituberculata Enderlein) ; vein $\mathrm{M}_{4}$ arising from discal cell much beyond $\mathrm{m}-\mathrm{cu}$ crossvein and distance between bases of $M_{2}$ and $M_{3}$ roughly as long as that between bases of $M_{3}$ and $M_{4}$; eye distinctly pilose; abdomen widest at segment 2 or $3 \ldots \ldots \ldots \ldots \ldots$ Coenomyia

Genus Anacanthaspis Röder, 1889 (Type-species: Anacanthaspis bifasciata Röder) - This genus contains only 1 species, bifasciata Röder 1889 known from Siberia and Manchuria. One subspecies, bifasciata japonica Shiraki 1932, is reported from Japan. For diagnoses see Nagatomi and Saigusa (1970) and the key to genera in this paper. Distribution: Siberia, Manchuria, Japan.

I have examined the specimens ( ${ }^{\top}$, 우) of bifasciata japonica. The anterior thoracic spiracle (as well as posterior thoracic one) is large and is roughly as long as the posterior width of humeral callus.

Genus Arthropeas Loew, 1850 (Type-species: Arthropeas sibirica Loew)-This genus contains 4 species: americana Loew 1861 from N. America, magna Johnson 1913 from N. America, sachalinensis Matsumura 1916 from Sakhalin, and sibirica Loew 1850 from Siberia, Manchuria (after Ouchi, 1943), and Korea (after Ouchi, 1943). Two subspecies or varieties, sibirica fenestralis Malloch 1932 from Tibet and sibirica semifusca Malloch 1932 from Tibet, are reported. For diagnoses see the key to genera in this paper. Distribution: Tibet, Korea, Manchuria, Siberia, Sakhalin, N. America.

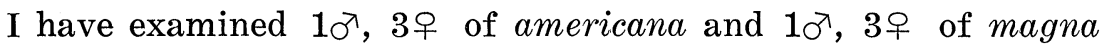
and add the following notes: cheeks rather well developed below eyes, mid-lower face not so large as in Coenomyia and Anacanthaspis, lower facets smaller than upper ones especially in americana but difference inconspicuous, convexity of metapleura gentle, scutellum roughly triangular or semicircular and over $1 / 2$ or not much less than $1 / 2$ as long as basal width, and abdomen widest at segment 1 or 2 .

In americana, sides of face bare, in antennal flagellum last segment over 1/2 as long as rest, anterior thoracic spiracle (as well as posterior thoracic one) much shorter than posterior width of humeral callus, mid-posterior margin of mesonotum without knob-like processes, small subscutellum present, postscutellum (including subscutellum) longer than in magna, convexity of metapleura more weak than in magna, mid-ventral part of hind coxa with a well developed 
knob-like process, vein between 1 st submarginal and 1st posterior cells much shorter than vein $R_{4}$, distance between apices of $R_{4}$ and $R_{5}$ somewhat longer than but never over twice that between apices of $\mathrm{R}_{5}$ and $\mathrm{M}_{1}$, and abdomen somewhat slender.

Whereas in magna, sides of face haired, in antennal flagellum last segment less than $1 / 2$ as long as rest, anterior thoracic spiracle (as well as posterior thoracic spiracle) about as long as posterior width of humeral callus, mid-posterior margin of mesonotum with a pair of small knob-like processes, subscutellum absent, postscutellum short as in Coenomyia and Anacanthaspis, convexity of metapleura more strong than in americana, hind coxa without mid-ventral process, vein between 1st submarginal and 1st posterior cells roughly as long as vein $R_{4}$, distance between apices of $R_{4}$ and $R_{5}$ over twice as long as that between apices of $R_{5}$ and $M_{1}$, and abdomen fairly robust.

Genus Coenomyia Latreille, 1796 (Type-species: Musca ferruginea Scopoli) - This genus contains 3 species: basalis Matsumura 1915 (=apicalis Matsumura 1915, comans Enderlein 1927, and japonica Séguy 1955) from Japan, bituberculata Enderlein 1921 from Tibet, Nepal, and Sikkim and ferruginea Scopoli 1763 from Europe and N. America. For diagnoses see Oldroyd (1966), Nagatomi and Saigusa (1970), and the key to genera in this paper. Distribution: Europe, Tibet, Nepal, Sikkim, Japan, N. America.

I have examined the specimens $\left(\sigma^{7}\right.$, 우) of basalis. In basalis anterior thoracic spiracle (as well as posterior thoracic one) small and much shorter than posterior width of humeral callus.

Genus Dialysis Walker, 1850 (Type-species: Dialysis dissimilis Walker, which is a synonym of elongata Say)-Triptotricha Loew 1872 is a synonym of this genus (after Leonard, 1930). Dialysis contains 12 species, of which 1 is known from Formosa and S. China (after Frey, 1954), 2 from Japan, and 9 from N. America. For diagnoses see the key to genera in this paper and the additional notes given below. For illustrations of $\sigma^{\top}$ genitalia see Hardy (1948). Distribution: Formosa, S. China, Japan, N. America.

The annulated portion of antennal segment 3 may easily change into an unsegmented, slender arista, the unarmed scutellum is in common with Arthropeas, and the slender abdomen is also seen in Odontosabula. All of these characters, as well as the mesonotum not so strongly arched, the 4 th posterior- and anal cell closed before wing margin, and the mid-ventral part of basistyle without a membranous area, seem to matter little to the family segregation.

In disparilis Bergroth 1889 and kesseli Hardy 1948, fore basitarsus with 2 terminal spurs (after Leonard, 1930 and Hardy, 1948), and in elongata Say 1823 vein $\mathrm{M}_{3}$ incomplete or entirely lacking and 
anal cell closed at wing margin (after Leonard, 1930).

I have examined the specimens ( $\sigma^{\top}$, 우) of iwatai Nagatomi 1953 and add the following notes: lower occiput somewhat developed behind eye, sides of face narrow as in Coenomyia and Anacanthaspis, in antenna each segment roughly as long as wide and segment 3 smaller in size than segment 2, anterior thoracic spiracle (as well as posterior thoracic one) much shorter than posterior width of humeral callus, convexity of metapleura weak, scutellum triangular or semicircular and roughly $1 / 2$ as long as basal width, postscutellum well developed, mid-ventral part of hind coxa with a small knob-like process (which may be inconspicuous), abdomen about as wide as thorax and segments 1-6 in $\sigma^{\top}$ and segments 1-4 in 우 nearly parallel sided.

Genus Odontosabula Matsumura, 1905 (Type-species: Odontosabula gloriosa Matsumura) - Stratioleptis Pleske, 1925 is a synonym of this genus (after Nagatomi and Saigusa, 1970). Odontosabula contains 3 species: czerskii Pleske 1925 from E. Siberia and Korea, gloriosa Matsumura 1905 (=pleskei Séguy 1926) from Japan (Kyushu), and licenti Séguy 1952 from Manchuria. But licenti is probably a synonym of czerskii. For diagnoses see Nagatomi and Saigusa (1970) and the key to genera in this paper. Distribution: Manchuria, Korea, E. Siberia, Japan.

I have examined the specimens ( $\sigma^{\top}$, 우) of czerskii and gloriosa. The thoracic spiracles fairly large and its anterior one over $1 / 2$ as long as posterior width of humeral callus.

I have noticed that there are 2 species in Japan. One is gloriosa (=pleskei) from Kyushu (Kagoshima Pref.) and the other is an undescribed form from Honshu (Nagano-, Gifu-, Fukui Pref.) which will be named in the near future.

\section{References}

Frey, R. (1954) : Studien über ostasiatische Dipteren. III. Rhachiceridae, Rhagionidae, Hilarimorphidae. Notulae Ent., 34, 1-25.

Hardy, D. E. (1948): New and little known Diptera from the California Academy of Sciences collection (Rhagionidae and Dorilaidae). Amer. Midland Nat., 41, $143-167$.

Leonard, M. D. (1930): A revision of the Dipterous family Rhagionidae (Leptidae) in the United States and Canada. Amer. Ent. Soc. Mem., 7, 1-181.

Nagatomi, A. (1975a) : Definition of Coenomyiidae (Diptera). I. Diagnoses of the family. Proc. Japan Acad., 51, 452-456.

Nagatomi, A., and Saigusa, T. (1970): The Coenomyiidae of Japan (Diptera). Mem. Fac. Agr. Kagoshima Univ., 7, 257-292.

Oldroyd, H. (1966) : Notes on Coenomyia Latreille (Diptera: Coenomyiidae). Beitr. Ent., 16, 953-963. 
Ouchi, Y. (1943): Contributiones ad Congnitionem Insectorum Asiae Orientalis 13. Notes on some Dipterous insects from Japan and Manchoukuo. Shanghai Sizenkagaku Kenkyusyo Ihô, 13, 483-492 (in Japanese with English summary). 